\title{
PENGARUH PERPUTARAN PERSEDIAAN, PERPUTARAN PIUTANG DAN PERPUTARAN KAS TERHADAP PROFITABILITAS PADA PERUSAHAAN SEKTOR INDUSTRI BARANG KONSUMSI YANG LISTING DI BURSA EFEK INDONESIA PERIODE 2015-2019
}

\author{
Atika Umamatul Ulya ${ }^{1}$, Andria Referli ${ }^{2}$, Milka Susana Theorupun ${ }^{3}$ \\ Fakultas Ekonomi Akuntansi \\ Universitas Boyolali \\ Jln. Pandanaran No. 405 Boyolali \\ e-mail: atikauulya09@gmail.com, andria.referli86@gmail.com, m.susana.theorupun@gmail.com
}

\begin{abstract}
ABSTRAK
Tujuan penelitian ini untuk memperoleh asumsi mengenai efek inventory turnover (perputaran persediaan), receivable turnover (perputaran piutang) serta cash turnover (perputaran kas) terhadap profitabilitas (profitability)pada perusahaan sektor industri barang konsumsi yang listing di BEI period 2015-2019. Jenis data yang digunakan merupakan data sekunder. Teknik pengambilan sampel memakai purposive sampling diperoleh 29 perusahaan. Semua data diuraikan memakai analisis regresi linier berganda, uji asumsi klasik, uji t, uji f serta koefisien determinasi.

Hasil penelitian memperlihatkan bahwa, ada pengaruh negatif serta tidak signifikan antara cash turnover (perputaran kas) terhadap profitability(profitabilitas), ditunjukkan dengan persamaan $\mathrm{Y}=-2.770-0.089 \mathrm{X}_{1}$ dengan nilai koefisien regresi sebesar -0.089 dan nilai t hitung -1.289 lebih kecil dari $t$ tabel 1.6556. Ada dampak positif serta tidak signifikan antara receivable turnover (perputaran piutang) terhadap profitability(profitabilitas), ditunjukkan dengan persamaan $\mathrm{Y}=-2.770+0.210 \mathrm{X}_{2}$ dengan nilai koefisien regresi sebesar 0.210 dan nilai t hitung 1.467 lebih kecil dari t tabel 1.6556. Terdapat pengaruh positif dan tidak signifikan antara inventory turnover terhadap profitability(profitabilitas), diperlihatkan dengan persamaan $\mathrm{Y}=-2.770+0.078 \mathrm{X}_{3}$ dengan nilai koefisien regresi sebesar 0.078 dan $t$ hitung 0.0557 lebih kecil dari t tabel 1.6556. Terdapat pengaruh dan tidak signifikan antara inventory turnover (perputaran persediaan), receivable turnover (perputaran piutang) serta cash turnover (perputaran kas), ditunjukkan menggunakan $\mathrm{f}$ value $1.110 \leq 2.67$ dengan koefisien determinasi sebesar $2.3 \%$.
\end{abstract}

Kata kunci :perputaran kas,perputaran piutang,perputaran persediaan,profitabilitas

\section{ABSTRACT}

The purpose of this study is to obtain an understanding of the impact of inventory turnover accounts receivable turnover and cash turnover on profitability in companies in the Consumer Goods Industr sector companies listed on the IDX for the 2015-2019 period. The type of data used is secondary data. The sampling technique used purposive sampling obtained 29 companies. All data were analyzed using classical assumption test, multiple linear regression analysis, t test, f test and coefficient of determination.

The results confirmed that, there was a negative and insignificant affect between cash turnover on profitability, indicated by the equation $Y=-2.770-0.089 X 1$ with a regression coefficient value of -0.089 and a t-count value of -1.289 smaller than $t$ table 1.6556. There is a positive and insignificant effect among receivables turnover on profitability, indicated by the equation $Y=-2.770+0.210 X 2$ with a regression coefficient value of 0.210 and the $t$-count value of 1.467 is smaller than t table 1.6556. There is a positive and insignificant effect between inventory turnover on profitability, indicated by the equation $Y=-2.770+0.078 X 3$ with a regression coefficient value of 0.078 and $t$ count 0.0557 smaller than $t$ table 1.6556. There is a significant and 
insignificant impact between cash turnover, bills receivable turnover and inventory turnover on profitability indicated via the calculated $f$ value of 1.110 smaller than $f$ table 2.67 with a coefficient of determination of $2.3 \%$.

Keywords: Cash turnover, Receivable turnover, Inventory turnover, Profitability

\section{Pendahuluan}

Consumer goods industry merupakan industri yang menarik dan memiliki kontribusi besar dalam memenuhi kebutuhan konsumen, sektor industri tersebut memproduksi kebutuhan pokok sehari-hari yaitu makanan ataupun barang konsumsi lainnya yang dibutuhkan dan produknya dapat dinikmati langsung oleh konsumen seiring dengan bertambahnya jumlah penduduk di Indonesia.

Peranan pentingnya terdapat pada salah satu sub sektor yaitu, sub sektor industri makanan dan minuman. Adapun sektor industri makanan menjadi penyumbang devisa terbesar dari total nilai ekspor industri pengolahan pada Januari-Februari 2020 yang mencapai USD 4,7miliar. Angka tersebut naik dibandingkan perolehan diperiode yang sama tahun sebelumnya sebesar USD 4,3 miliar. Industri makanan juga menjadi penyumbang paling besar pada capain nilai ekspor industri pengolahan pada Februari 2020, yang tercatat mencapai USD 2,45 miliar atau berkontribusi 22,26\%, ekspor industri makanan naik 8,94\% dibanding Januari 2020.

Tolak ukur berhasil atau tidaknya suatu perusahaan dapat dilihat dari profitabilitasnya. Penelitian ini menggunakan Return On Asset sebagai alat ukur dari rasio profitabilitas karena menurut (Lukman Syamsuddin,2011:63) menyatakan ROA memberikan penjelasan ihwal keahlian perusahaan secara keseluruhan dalam menciptakan profit dengan keseluruhan aset yang disediakan. Modal kerja mempunyai arti yang sangat krusial bagi operasional. Disamping itu manajemen modal kerja juga memiliki tujuan tertentu yang ingin dicapai. Menurut (Kasmir,2014:252) menyatakan bahwa setiap perusahaan berusaha memaksimalka kebutuhan modal kerjanya, dengan terpenuhi modal kerjanya maka perusahaan dapat meningkatkan perolehan profitnya. Modal kerja memiliki tiga unsur yakni kas, piutang serta persediaan. Ketiga unsur tersebut dapat dikelola dengan cara yang berlainan untuk meningkatkan pertumbuhan laba perusahaan (Lazaridis dan Tryfonidis,2006:11).

Adapun penelitian ini untuk melihat bagaimana efek inventory turnover (perputaran persediaan), receivable turnover (perputaran piutang) serta cash turnover (perputaran kas) secara masing-masing maupun bersama-sama terhadap profitability(profitabilitas) . Penelitian ini bertujuan untuk memperoleh pandangan perihal efek inventory turnover (perputaran persediaan), receivable turnover (perputaran piutang) serta cash turnover (perputaran kas) terhadap profitability(profitabilitas).

Atas dasar fenomena dan latar belakang yang telah dikemukakan maka penulis tertarik buat mengambil judul “.Pengaruh Perputaran Persediaan, Perputaran Piutang dan Perputaran Kas Terhadap Profitabilitas Pada Perusahaan Sektor Industri Barang Konsumsi yang Listing Di Bursa Efek Indonesia Periode 2015-2019"

\section{Landasan Teori dan Pengembangan Hipotesis}

\subsection{Pengertian Industri}

Industri menurut Undang-Undang Republik Indonesia No Tiga Tahun 2014 Berkenaan perindustrian, industri merupakan keseluruhan bentuk kegiatan ekonomi yang mengolah bahan baku dan/atau memanfaatkan sumber daya industri sehingga menghasilkan barang yang mempunyai nilai tambah atau manfaat lebih tinggi termasuk jasa industri.

\subsection{Profitabilitas (Profitability)}

Menurut (Kasmir,2014:196) menyatakan untuk menilai keahlian perusahaan dalam mencari profit dapat memakai rasio profitabilitas. Serta pula menyampaikan ukuran taraf 
kemampuan manajemen suatu perusahaan. Kondisi ini dicermati menggunakan keuntuntungan yang didapatkan dari penjualan serta pendapatan investasi. Pada penelitian ini menggunakan Return On Asset sebagai alat ukur dari rasio profitabilitas karena menurut (Lukman Syamsuddin, 2011:63) menyatakan bahwa ROA memberikan penjelasan ihwal keahlian perusahaan secara keseluruhan didalam menciptakan keuntungan dengan jumlah keseluruhan aset yang tersedia di dalam perusahaan. Rumus untuk mengukur ROA sebagai berikut:

\subsection{Perputaran Kas (Cash Turnover)}

$$
R O A=\frac{\text { Earning After Interest and Tax }}{\text { Total Asset }}
$$

Menurut (Halim,2015:166) menyatakan Perputaran kas yakni gambaran berapa kali uang kas berputar pada satu rentan waktu. Semakin meningkat perputaran kas semakin bagus, sebab ini berarti semakin tinggi efisiensi penggunaan kasnya maka profit yang diperoleh akan semakin tinggi pula menurut (Bambang Riyanto,2010:254).. Untuk mengukur rasio perputaran kas dapat menggunakan rumus sebagai berikut:

$$
\text { Rasio Perputaran Piutang }=\frac{\text { Penjualan Bersih }}{\text { Rata }- \text { Rata Piutang }}
$$

\subsection{Perputaran Piutang (Receivable Turnover)}

Menurut (Kasmir,2016:176) perputaran piutang yakni rasio yang digunakan untuk alat pengukuran penagihan piutang dalam satu rentan waktu atau berapa kali dana yang tertanam dalam piutang ini berputar dalam satu tahun. Bertambah tinggi perputaran piutang menandakan bahwa perusahaan semakin baik dalam mengelola piutang menurut (Sutrisno,2007:220). Untuk mengukur rasio perputaran piutang dapat menggunakan rumus sebagai berikut :

$$
\text { Rasio Perputaran Piutang }=\frac{\text { Penjualan Bersih }}{\text { Rata }- \text { Rata Piutang }}
$$

\subsection{Perputaran Persediaan (Inventory Turnover)}

Menurut (Kasmir,2014:180) rasio yang dipergunakan sebagai alat ukur berapa kali anggaran yang ditetapkan pada persediaan berputar pada satu tahun menggunakan rasio perputaran persediaan. Perputaran persediaan bertambah besar maka semakin tinggi juga keuntungan yang didapatkan. Untuk mengukur rasio perputaran persediaan dapat menggunakan rumus sebagai berikut:

$$
\text { Rasio Perputaran Persediaan }=\frac{\text { Harga Pokok Penjualan }}{\text { Rata }- \text { Rata Persediaan }}
$$




\subsection{Kerangka Pemikiran}

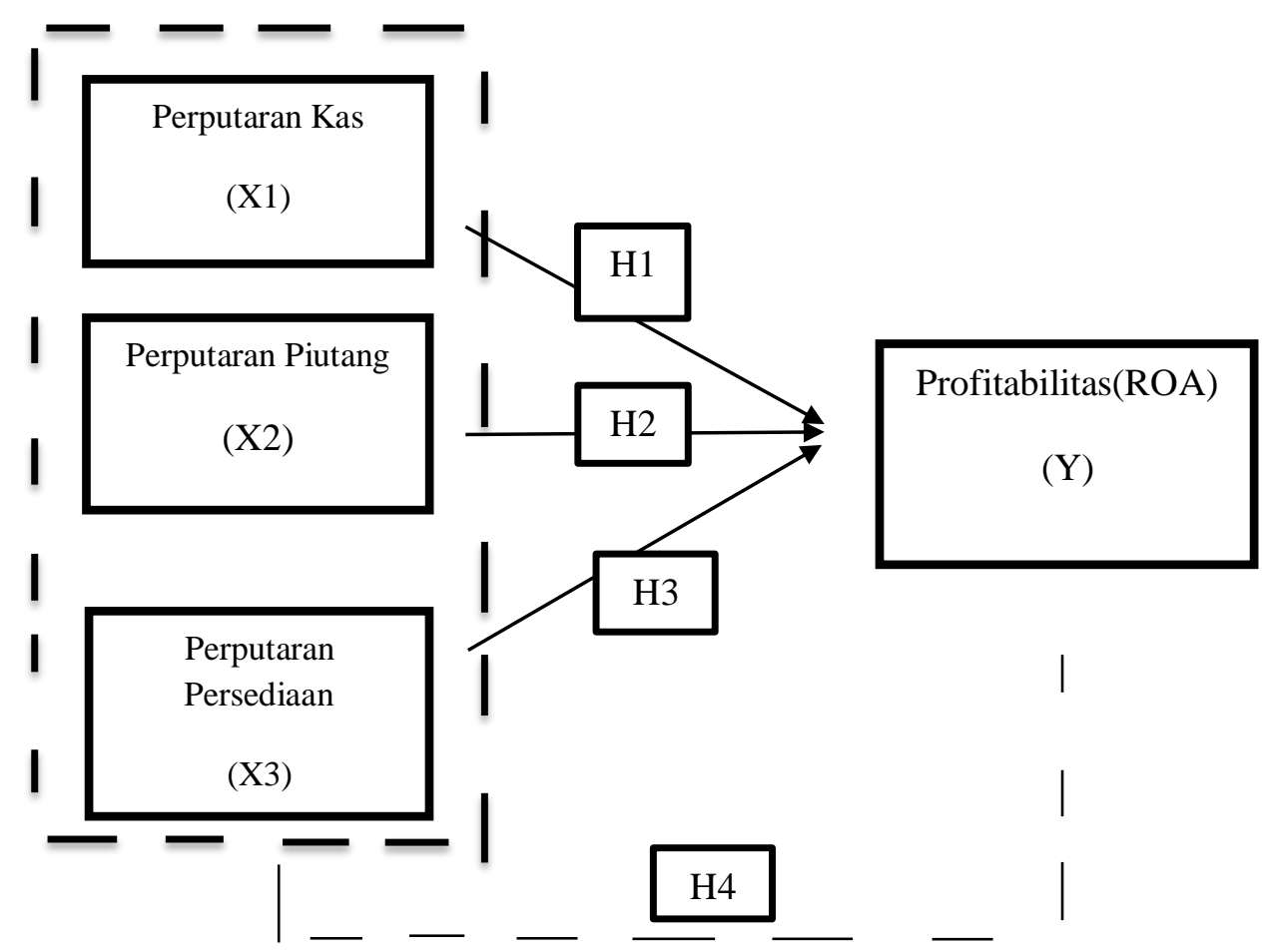

\section{Metode Penelitian}

Gambar 2.1

Sesuai jenis data yang ditetapkan penelitian ini merupakan penelitian kuantitatif melalui analisis verifikatif serta pendekatan penelitian diskriptif, digunakan untuk menguraikan efek variabel bebas terhadap variabel terikat. Perusahaan sektor industri barang konsumsi yang listing di BEI periode 2015-2019 menjadi populasi dalam penelitian ini sejumlah 55 perusahaan. Pada penelitian ini didapat sampel yakni 29 perusahaan, pengambilan sampel memakai metode purposive sampling. Metode dokumentasi dipergunakan sebagai cara pengumpulan data,merupakan cara pengumpulan data menggunakan cara mengambil data sekunder dari laporan keuangan yang sudah diaudit melalui situs resmi BEI yaitu https://www.co.id.

\section{Hasil dan Pembahasan}

\subsection{Diskripsi Data}

Menurut (Asep Saefuddin,2009:29) bahwa diskripsi data yaitu upaya manampilkan data supaya data tersebut dapat dipaparkan dengan baik dan diinterpretasikan dengan mudah. Sebelum pengujian hipotesis dilakukan data yang digunakan harus terbebas dari asumsi klasik karena, pengujian ini dilakukan untuk menguji kualitas sehingga data diketahui keabsahannya dan menghindari terjadinya estimasi bias. Oleh karena itu peneliti melakukan transformasi data. Menurut (Ghozali,2019) menyatakan bahwa tranformasi data merupakan salah satu cara menormalkan data dengan merubah skala pengukuran data asli menjadi bentuk lain yang masih memiliki nilai yang sama sehingga data dapat memenuhi kriteria uji asumsi klasik. Pengubahan data kebentuk LN dimaksudkan untuk mengurangi adanya kesalahan asumsi klasik. Bila data yang digunakan terjadi kekliruan atau tidak berdistribusi secara normal maka pengubahan dilakukan menggunakan kebentuk LN. 
1. Pengaruh perputaran kas(cash turnover) terhadap profitabilitas(profitability)

Diperoleh uji t untuk perputaran kas (cash turnover) (LN_X $\mathrm{X}_{1}$ ) lebih besar dari besarnya $\mathrm{t}_{\text {hitung }}$ adalah -1.289 dan nilai $\mathrm{p}$ value (sig) 0.199 , alpha 0.05 . Menghitung $\mathrm{t}$ tabel yaitu $\mathrm{df}=(\mathrm{n}-\mathrm{k})=(145-3)=142$. Jadi $\mathrm{t}$ table $=\mathrm{t}_{(0.05) ;(142)}=1.6556$, sehingga $(-$ $1.289 \leq 1.6556)$ menggunakan nilai sig lebih besar dari $\alpha=0.05$. Maka perputaran kas berpengaruh negatif serta tidak signifikan terhadap profitabilitas. Menurut (Bambang Riyanto, 2008:254) menyatakan semakin tinggi perputaran kas akan semakin baik, karena ini berarti semakin tinggi efisiensi penggunaan kasnya dan keuntungan yang diperoleh akan semakin tinggi pula. Namun dalam penelitian ini perputaran kas perlu diatur dan dikelola dengan baik, kas yang besar dapat digunakan oleh perusahaan untuk membiayai beban biaya operasional sehingga dapat menambah profitabilitas perusahaan, tetapi apabila terlalu besar mengakibatkan sejumlah dana menganggur. Sebaliknya, apabila jumlah kas terlalu kecil akan membahayakan bagi perusahaan karena akan menimbulkan hambatan untuk berbagai pembayaran perusahaan sebagai akibatnya akan mengganggu aktivitas operasional perusahaan dan dapat menyebabkan penurunan profitabilitas perusahaan. Pengujian ini searah menggunakan penelitian terdahulu yang dibuat oleh (Alhania Farahanny Sofyan\&Muhammad Saifi,2018) bahwa perputaran kas berpengaruh negatif serta tidak signifikan terhadap profitabilitas sesuai dengan pertumbuhan selama periode 2015-2019 di perusahaan sektor industri barang konsumsi

2. Pengaruh perputaran piutang(receivable turnover) terhadap profitabilitas(profitability)

Diperoleh uji t untuk perputaran piutang (receivable turnover) ( $\mathrm{LN} \_\mathrm{X}_{2}$ ) lebih besar dari besarnya $\mathrm{t}$ hitung adalah 1.467 dengan nilai $\mathrm{p}$ value (sig) 0.145 , alpha 0.05. Menghitung besarnya $\mathrm{t}$ tabel yaitu $\mathrm{df}=(\mathrm{n}-\mathrm{k})=(145-3)=142$. Jadi $\mathrm{t}$ table $=\mathrm{t}_{\mathrm{t}(0.05) ;(142)}=16556$, sehingga $(1.467 \leq 1.556)$ dengan nilai sig lebih besar dari alpha 0.05.0Maka perputaran piutang berpengaruh positif serta tidak signifikan terhadap profitabilitas.Semakin meningkat perputaran piutang juga mengindikasikan bahwa perusahaan semakin efektif saat mengelola piutang (Sutrisno, 2007:220). Kondisi ini tentunta bagus bagi perusahaan, kebalikannya apabila perputaran piutang semakin rendah ada kelebihan aset lancar yang ditempatkan dalam piutang. Keadaan ini berarti semakin meningkat perputaran piutang maka semakin cepat tagihan yang masuk sebagai akibatnya perusahaan bisa mengubah tagihan yang masuk menjadi kas. Pengujian ini searah menggunakan penelitian yang dibuat oleh (Dilla Ramadani\&Rosyeni Rasyid,2019) bahwa perputaran piutang berpengaruh positif serta tidak signifikan terhadap profitabilitas sesuai menggunakan pertumbuhan selama periode 2015-2019 pada perusahaan sektor industri barang konsumsi.

3. Pengaruh perputaran persediaan(inventory turnover) terhadap profitabilitas(profitality)

Hasil uji $\mathrm{t}$ perputaran persediaan(inventory turnover) ( $\left.\mathrm{LN}_{-} \mathrm{X}_{3}\right)$ lebih besar dari besarnya dari besarnya $t$ hitung adalah 0.557 dengan nilai $\mathrm{p}$ value (sig) 0.579 , alpha 0.05. Menghitung besarnya $\mathrm{t}$ tabel yaitu $\mathrm{df}=(\mathrm{n}-\mathrm{k})=(145-3)=142$. Jadi $\mathrm{t}$ table $=_{\mathrm{t}(0.05) ;(142)}=1.6556$, sehingga $(0.557 \leq 1.6556)$ dengan nilai $\mathrm{p}$ value (sig) lebih besar dari alpha 0.05. Maka perputaran persediaan berpengaruh positif serta tidak signifikan terhadap profitabilitas. Menurut (Lukman Syamsuddin,2002:236) perputaran persediaan semakin meningkat, sehingga semakin tinggi juga laba yang didapatkan. Pastinya kondisi ini baik untuk perusahaan, kebalikannya apabila perputaran persediaan semakin rendah menunjukan bahwa biaya yang akan dikeluarkan sebagai perawatan barang digudang maka semakin rendah 
pula profitabilitas. Pengujian ini searah menggunakan penelitian yang dibuat oleh (Dilla Ramadani\&Rosyeni Rasyid,2019) bahwa perputaran persediaan berpengaruh positif serta tidak signifikan terhadap profitabilitas sesuai menggunakan pertumbuhan selama periode 2015-2019 pada perusahaan sektor industri barang konsumsi.

4. Pengaruh perputaran persediaan (inventory turnover), perputaran piutang (receivable turnover) dan perputaran kas (cash turnover) terhadap profitabilitas (profitability)

Uji $f$ menunjukkan bahwa nilai $\mathrm{f}_{\text {hitung }}$ sebesar 1.110 dan $\mathrm{f}_{\text {tabel }}$ yaitu $\mathrm{df}=(\mathrm{n}-\mathrm{k})=(145$ -

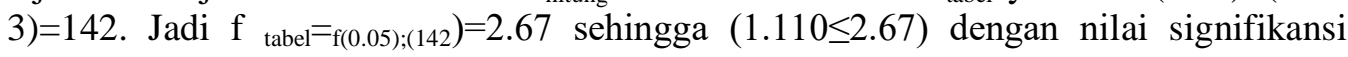
$0.347 \geq 0.05$, sehingga dapat disimpulkan bahwa ada pengaruh serta tidak signifikan antara perputaran kas (LN_X1), perputaran piutang ( $\left.L N \_X 2\right)$, perputaran persediaan (LN_X3) terhadap profitabilitas (ROA) (LN_Y). Yang artinya pada penelitian ini mampu membuktikan melalui hasil uji koefisien determinasi niali $\mathrm{R}^{2}$ sebesar 0.023 atau $2.3 \%$. Dari hasil uji tersebut menjelaskan bahwa profitabilitas $2.3 \%$ dipengaruhi oleh perpuatran kas, perpuatran piutang serta perputaran persediaan sedangkan $97.7 \%$ dipengaruhi oleh variabel lain yang tidak dilibatkan dalam penelitian ini.

\section{Kesimpulan}

Secara mandiri cash turnover (perputaran kas) berpengaruh negatif serta tidak signifikan terhadap profitability (profiatbilitas), bahwa taraf daya laba perusahaan akan menurun jika perusahaan menambah perputaran kas. Receivable turnover (Perputaran piutang) berpengaruh positif tidak signifikan terhadap profitabilitas. Situasi ini tentunya bagus untuk perusahaan, kebalikannya jika perputaran piutang semakin rendah terdapat kelebihan aset lancar yang ditempatkan dalam piutang. Hal ini berarti semakin tinggi perputaran piutang maka semakin cepat tagihan yang masuk sebagai akibatnya perusahaan dapat mengganti tagihan yang masuk sebagai kas. Inventory Turnover (Perputaran persediaan) berpengaruh positif serta tidak signifikan terhadap profitability (profitabilitas), pastinya kondisi ini bagus buat perusahaan, kebalikannya bila perputaran persediaan semakin rendah menunjukkan bahwa perawatan bahan digudang membutuhkan biaya yang sangatlah besar sebagai akibatnya biaya yang dikeluarkan terlalu tinggi. Apabila biaya yang ditanggung perusahaan untuk perawatan barang digudang besar maka semakin rendah pula profitabilitas perusahaan. Secara simultan terdapat pengaruh dan tidak signifikan antara perputaran kas, perputaran piutang serta perputaran persediaan terhadap profitabilitas, dengan berupa dampak sebesar $2.3 \%$ dan sisanya $97.7 \%$ tidak dimasukkan pada penelitian ini yang di pengaruhi variabel lain. 


\section{DAFTAR PUSTAKA}

Alhania Farahanny Sofyan, M. S. (2018). MODAL KERJA DAN PROFITABILITAS PADA PERUSAHAAN FOOD AND BEVERAGES( Studi pada Perusahaan Sub Sektor Food and Beverages yang Terdaftar Di Bursa Efek Indonesia Periode 2014-2018 ). 73(1), 169-177.

Ghozali, Imam.2019. Aplikasi Analisis Multivariete Dengan Program IMB SPSS 23 (Edisi 8) Cetakan ke VIII. Semarang: Badan Penerbitan Universitas Diponogoro.

Halim, Abdul. 2015. Manajemen Keuangan Bisnis Konsep dan Aplikasinya. Jakarta: Mitra Wacana Media.

https://kemenperin.go.id/artikel/21637/Ekspor-Manufaktur-Lampaui-USD-21-Miliar,-IndustriMakanan-Jadi-Andalan

Kasmir.2014. Analisis Laporan Keuangan. Jakarta: PT.Raja Grafindo Persada.

Kasmir.2016. Pengantar Manajemen Keuangan. Edisi Kedua. Jakarta: Prenadamedia Grup.

Lazaridis and Tryfonidis. 2006. The relationship between working capital management and profitability(profitabilitas) of listed companies in the Athens Stock Exchange. Journal of Business Finance \& Accounting, Vol.19, No 1, pp. 1-12

Ramadani, D., \& Rasyid, R. (2019). Pengaruh Perputaran Kas, Perputaran Piutang dan Perputaran Persediaan terhadap Profitabilitas pada Perusahaan Makanan dan Minuma yang Terdaftar di Bursa Efek Indonesia Periode 2013 - 2017. 01, 96-106.

Riyanto, Bambang. 2010. Dasar-Dasar Pembelajaran Perusahaan, Edisi Keempat. Yogyakarta: BPFE.

Saefuddin, Asep. 2009. Statistika Dasar. Jakarta: Grasindo.

Sutrisno. 2007. Manajemen Keuangan Teori, Konsep dan Aplikasi. Yogyakarta: Ekonesia.

Syamsuddin, Lukman. 2011. Manajemen Keuangan Perusahaan. Jakarta:Rajawali.

Undang-Undang RI No.3 Tahun 2014 tentang Perindustrian Lembaran Negara Republik Indonesia TAHUN 2014 No.4

www.idx.co.id 